\title{
PENERAPAN MODEL PEMBELAJARAN KOOPERATIF TIPE THINK PAIR SHARE (TPS) UNTUK MENINGKATKAN HASIL BELAJAR PKn SISWA KELAS V SDN 3 TORONIPA
}

\author{
Sitti Nurhazisa ${ }^{1, a)}$, Lisnawati Rusmin ${ }^{2}$ \\ ${ }^{1}$ Alumni Jurusan Pendidikan Guru Sekolah Dasar, FKIP Universitas Halu Oleo, \\ Jl. H.E.A. Mokodompit Kendari 93232, Indonesia \\ ${ }^{2}$ Dosen FKIP Universitas Halu Oleo, Jl. H.E.A. Mokodompit Kendari 93232, \\ Indonesia \\ a)e-mail: sittinurhazisa073@gmail.com
}

\begin{abstract}
ABSTRAK
Penelitian ini bertujuan untuk meningkatkan hasil belajar siswa pada materi pokok kebebasan berorganisasi melalui penerapan model pembelajaran kooperatif tipe TPS. Penelitian ini menerapkan desain penelitian tindakan kelas dengan subyek penelitian siswa kelas V SDN 3 Toronipa. Teknik analisis data dalam penelitian ini adalah statistik deskriptif. Adapun prosedur dalam penelitian ini adalah: 1) Perencanaan, 2) Pelaksanaan Tindakan, 3) Observasi dan Evaluasi, 4) Refleksi. Hasil yang diperoleh yang berkaitan dengan hasil belajar siswa pada siklus I adalah 63,63\%atau sebanyak 7 orang dari 11 siswa yang tuntas memperoleh nilai $\geq 70$ dengan nilai rata-rata 67,72. Sedangkan hasil belajar siswa pada siklus II meningkat menjadi $90,90 \%$ atau sebanyak 10orang dari 11 siswa yang tuntas memperoleh nilai $\geq 70$ dengan nilai rata-rata 75,45 .
\end{abstract}

Kata kunci: Hasil Belajar, Model Pembelajaran Kooperatif Tipe TPS

\section{THE IMPLEMENTATION OF COOPERATIVE LEARNING MODEL THINK PAIR SHARE (TPS) TYPE TO IMPROVE STUDENT LEARNING RESULT PKn IN CLASS V SDN3 TORONIPA}

\begin{abstract}
This study aims to improve student learning outcomes in the subject matter of freedom of organization through the application of TPS type cooperative learning models. This study applies a classroom action research design with research subjects of grade V students of SDN 3 Toronipa. Data analysis techniques in this study are descriptive statistics. The procedures in this study are: 1) Planning, 2) Implementation of Action, 3) Observation and Evaluation, 4) Reflection. The results obtained relating to student learning outcomes in the first cycle were $63.63 \%$ or as many as 7 people from 11 students who completed a score of $\geq 70$ with an average value of 67.72. While student learning outcomes in cycle II increased to $90.90 \%$ or as many as 10 people from 11 students who completed a score of $\geq 70$ with an average value of 75.45 .
\end{abstract}

Keyword: : Learning Outcomes, TPS Type Cooperative Learning Model 


\section{Pendahuluan}

Pendidikan merupakan salah satu istilah yang sering dilontarkan oleh berbagai pihak sebagai alat ampuh untuk melakukan perubahan terhadap kehidupan suatu masyarakat ke arah yang lebih baik. Begitu pentingnya pendidikan maka semua bangsa dan Negara menempatkan pendidikan sebagai sesuatu yang penting dan utama termasuk bangsa Indonesia, sebagaimana yang dapat dilihat pada alinea ke IV pembukaan UUD 1945 mengesankan bahwa salah satu tujuan nasional bangsa Indonesia adalah mencerddaskan kehidupan bangsa (Iskandar, 2012, p.7).

Setiap model pembelajaran mempunyai karakteristik tertentu dengan segala kelebihan dan kelemahan masingmasing. Suatu pembelajaran mungkin baik untuk suatu tujuan tertentu, pokok bahasan maupun situasi dan kondisi tertentu, tetapi tidak tepat untuk situasi lain. Demikian pula suatu model pembelajaran yang dianggap baik untuk suatu pokok bahasan yang disampaikan oleh guru tertentu, kadang belum tentu berhasil dibawakan oleh guru lain.

Pendidikan Kewarganegaraan di sekolah dasar dimaksudkan sebagai suatu proses belajar mengajar dalam rangka membantu peserta didik agar dapat belajar dengan baik dan membentuk manusia Indonesia seutuhnya dalam pembentukan karakter bangsa yang diharapkan mengarah pada penciptaan suatu masyarakat yang menempatkan demokrasi dalam kehidupan berbangsa dan bernegara yang berlandaskan pada Pancasila, UUD, dan norma-norma yang berlaku di masyarakat yang diselenggarakan selama enam tahun (Ahmad Susanto, 2012, p.227).

Berdasarkan observasi yang dilakukan peneliti pada proses pembelajaran yang terjadi di kelas VSDN3 Toronipa adalah pembelajaran terkesan monoton dan hanya menggunakan metode konvensional (ceramah dan tanya-jawab) sehingga siswa hanya memperoleh informasi dari apa yang disampaikan di depan kelas.Sehingga hasil belajar siswa terhadap materi kebebasan berorganisasi tahun ajaran 2014/2015 semester genap menunjukan bahwa dari 14 siswa, hanya 9 siswa atau $64,28 \%$ yang mencapai kriteria ketuntasan minimal (KKM) yang ditetapkan sekolah yaitu 70 .

Dari hasil pengamatan tersebut, peneliti mencoba merefleksikan tindakan guru tersebut dengan pengalaman peneliti sebagai mahasiswa dan calon guru. Berdasarkan hasil refleksi tersebut, peneliti mencoba melakukan perbaikan pembelajaran yang masih lebih banyak kekurangan sebanding dengan guru kelas tersebut. Peneliti lakukan demi memperbaiki kinerja sebagai calon guru di masa yang akan datang. Oleh karena itu, peneliti memutuskan untuk melakukan penelitian tindakan kelas (PTK) dengan menerapkan model pembelajaran kooperatif tipe TPS.

Dalam model pembelajaran kooperatif tipe TPS ini, ketika guru menerangkan di depan kelas, siswa duduk berpasangan dalam kelompoknya. Guru memberikan pertanyaaan di kelas. Lalu, siswa diperintahkan untuk memikirkan jawaban, kemudian siswa berpasangan dengan masing-masing pasangannya untuk mencari kesepakatan jawaban terakhir, guru meminta siswa untuk membagi jawaban kepada seluruh siswa di kelas (Slavin dalam M. Thobroni, 2015, p.246). Selain itu, melalui pembelajaran kooperatif tipe TPS merupakan jenis pembelajaran kooperatif yang dirancang untuk mempengaruhi pola interaksi siswa (La Iru dan La Ode Safiun Arihi, 2012,p.60).

Berdasarkan latar belakang di atas dan hasil penelitian Nursayang (2012) yang menunjukkan ketuntasan belajar siswa meningkat menjadi $88,23 \%$ dengan rata-rata nilai 82,76 dengan menggunakan model pembelajaran kooperatif tipe TPS, maka rumusan masalah dalam penelitian ini adalah "Apakah penerapan model pembelajaran 
kooperatif tipe TPSdapat meningkatkan hasil belajar PKn pada materi pokok kebebasan berorganisasi siswa kelas VSDN 3 Toronipa? Penelitian ini bertujuan untuk meningkatkan hasil belajar PKn siswa Kelas VSDN 3 Toronipa pada materi pokok kebebasan berorganisasi melalui penerapan model pembelajaran kooperatif tipeTPS.Hasil dari penelitian ini diharapkan dapat memberikan informasi dalam dunia pendidikan berupa gambaran mengenai sebuah teori yang menyatakan bahwa peningkatan hasil belajar PKn pada materi kebebasan berorganisasi dapat dilakukan dengan menggunakan model pembelajaran kooperatif tipe Think Pair Share (TPS).

\section{Metode Penelitian}

Jenis penelitian yang digunakan dalam penelitian ini adalah penelitian tindakan kelas.Penelitian tindakan kelas adalah penelitian yang dilaksanakanoleh guru di dalam kelas. Ciri-ciri khusus dari penelitian tindakan kelas yaitu:1) penelitian tindakan kelas dilaksanakan oleh guru itu sendiri, 2) penelitian tindakan kelas berangkat dari permasalahan nyata di kelas, 3) penelitian tindakan kelas mempersyaratkan adanya tindakan yang berlanjut untuk memperbaiki proses pembelajaran, 4) adanya refleksi diri. Penelitian ini dilaksanakan di SDN3 Toronipa pada kelas V semester genap tahun pelajaran 2015/2016. Subjek dalam penelitian ini adalah guru sebagai peneliti dan siswa kelas VSDN3 ToronipaKabupaten Konawe dengan jumlah siswa 11 orang yang terdiri dari 7 siswa laki-laki dan 4 siswa perempuan. Prosedur dalam penelitian ini adalah sesuai dengan langkah-langkah PTK yaitu perencanaan, pelaksanaan tindakan, observasi, evaluasi dan refleksi.

Jenis data dalam penelitian ini adalah data kualitatif dan data kuantitatif. Data kualitatif berupa kegiatan proses pembelajaran yang dilaksanakan oleh guru dan juga aktivitas siswa dalam mengikuti proses pembelajaran dan data kuantitatif berupa tes hasil belajar siswa. Data kualitatif digunakan untuk menghimpun data tentang pelaksanaan proses pembelajaran yang dilaksanakan oleh guru. Untuk memperoleh data kualitatif digunakan lembar observasi. Data kuantitatif diperoleh melalui tes. Data kuantitatif, yaitu berupa hasil belajar, diambil melalui tes tertulis dalam bentuk essay pada setiap akhir siklus. Analisis data yang digunakan dalam Penelitian Tindakan Kelas (PTK) ini adalah menggunakan statistik deskriptif untuk menghitung nilai siswa, rata-rata nilai siswa, ketuntasan belajar, keberhasilan aktivitas mengajar guru dan keberhasilan aktivitas belajar siswa. Langkah-langkah analisis data adalah sebagai berikut:

a. Menentukan nilai siswa ditentukan skor yang diperoleh siswa pada tes yang dilakukan dengan rumus :

Nilai Siswa $=\frac{\text { Skor perolehan }}{\text { Skor Maksimum }} \times 100$

b. Menghitung persentase ketuntasan belajar dengan menggunakan rumus sebagai berikut :

presentase $=\frac{\sum \bar{X}}{n} x 100 \%$

Dengan:

$\Sigma \bar{X}=$ Jumlah siswa pada kategori ketuntasan belajar.

$\mathrm{n}=$ Jumlah siswa secara keseluruhan.

c. Menentukan Rata - rata Nilai Siswa

Rata-rata $=\frac{\text { Jumlah nilai seluruh siswa }}{\text { Jumlah } \text { siswa }}$

(Imas Kurniasih dan Berlin Sani, 2014, p.84)

d. Menentukan keberhasilan aktivitas mengajar guru dan belajar siswa

$=\frac{\text { Jumlah perolehan siswa }}{\text { Jumlah skor maksimum }} \times 100 \%$

(Imas Kurniasih dan Berlin Sani, 2014, p.84)

Indikator kinerja dalam penelitian ini adalah indikator tentang keterlaksanaan skenario pembelajaran dan indikator peningkatan hasil belajar 
PKn siswa dalam penelitian ini. Setiap siswa dikatakan tuntas belajarnya (ketuntasan individu) jika proposisi jawaban benar siswa $\geq 70$. Suatu kelas dikatakan tuntas belajarnya (secara klasikal) jika dalam kelas tersebut $\geq 80 \%$ siswa yang telah tuntas belajarnya sesuai dengan KKM yang telah ditetapkan sekolah. Ketuntasan aktivitas mengajar guru dan ketuntasan aktivitas belajar siswa dianggap berhasil apabila dalam pelaksanaan pembelajaran skenario pembelajaran mencapai minimal $80 \%$ dari keseluruhan skenario pembelajaran.

\section{Hasil Penelitian dan Pembahasan}

Hasil observasi kegiatan mengajar guru pada siklus I pertemuan pertama menunjukkan bahwa skor perolehan guru adalah 8 sedangkan skor maksimum 12. Persentase keberhasilan aktivitas mengajar guru diperoleh dari perbandingan antara skor perolehan guru dan skor maksimum dikalikan seratus persen, maka persentase keberhasilan aktivitas mengajar guru pertemuan pertama adalah $66 \%$. Pada pertemuan kedua siklus I menunjukkan bahwa skor perolehan guru adalah 9 sedangkan skor maksimum 12. Maka persentase keberhasilan aktivitas mengajar guru pertemuan kedua adalah $75 \%$.

Hasil observasi aktivitas belajar siswa pada siklus I pertemuan pertama menunjukkan bahwa skor yang diperoleh adalah 7 sedangkan skor maksimum adalah 12. Persentase keberhasilan aktivitas belajar siswa diperoleh dari perbandingan antara skor perolehan dari aktivitas belajar siswa dan skor maksimum dikalikan seratus persen, maka persentase keberhasilan aktivitas belajar siswa pertemuan pertama adalah 58\%. Pada pertemuan kedua siklus I menunjukkan skor yang diperoleh dari aktivitas belajar siswa adalah 8, sedangkan skor maksimum 12 . Maka persentase keberhasilan aktivitas belajarsiswa pada pertemuan kedua adalah $66 \%$

Berdasarkan tes yang dilakukan menunjukan bahwa hasil belajar .matematika siswa setelah menerapkan model pembelajaran kooperatif tipe TPS khususnya pada materi pokok kebebasan berorganisasi, hasil tes menunjukan bahwa hanya beberapa siswa yang mencapai nilai $\geq 70$. Dari 11 siswa kelas $\mathrm{V}$ yang memperoleh nilai $\geq 70$ sebanyak 4 siswa atau dengan persentase $36,37 \%$ siswa yang mencapai KKM, sedangkan yang memperoleh nilai $<70$ sebanyak 7 siswa atau dengan persentase $63,63 \%$ dengan nilai rata-rata 67,72 .

Hasil analisis ketuntasan belajar siswa pada penelitian hasil belajar secara klasikal dapat dilihat pada tabel berikut ini.

Tabel 1. Analisis Ketuntasan Hasil Belajar Siswa Pada Siklus I

\begin{tabular}{|c|c|c|c|c|}
\hline No & Ketuntasan & Skor & $\begin{array}{c}\text { Jumlah } \\
\text { siswa }\end{array}$ & $\begin{array}{c}\text { Persentase } \\
(\mathbf{\%})\end{array}$ \\
\hline 1 & Tuntas & $70-100$ & 10 & $90,90 \%$ \\
\hline 2 & Belum Tuntas & $0-69$ & 1 & $9,1 \%$ \\
\hline \multicolumn{2}{|c|}{ Total } & 11 & $100 \%$ \\
\hline
\end{tabular}

Berdasarkan hasil observasi pada siklus I, guru dan siswa telah melakukan sebagian kegiatan pembelajaran dengan baik.Namun demikian, masih terdapat kekurangan-kekurangan yang perlu diperbaiki antara lain, guru kurang memberikan motivasi kepada siswa untuk serius dan antusias dalam mengikuti kegiatan pembelajaran, guru tidak memberikan batasan waktu kepada siswa dalam mengerjakan LKS, dan penghargaan yang diberikan kepada siswa hanya berupa pujian.

Berdasarkan hasil tes belajar siswa pada siklus I, siswa yang memperoleh nilai $\geq 70$ sebanyak 7 orang 
siswa atau sebesar $63,63 \%$ dengan nilai rata-rata 60,52. Secara klasikal mencapai persentase ketuntasan yaitu $63,63 \%$ belum mencapai target yaitu $80 \%$. hasil belajar PKn siswa pada siklus I yang belum memenuhi indikator keberhasilan dalam penelitian ini, maka penelitian ini dilanjutkan pada tindakan siklus II.

Hasil observasi kegiatan mengajar guru pada siklus II pertemuan pertama menunjukkan bahwa skor perolehan guru adalah 10 sedangkan skor maksimum 12. Persentase keberhasilan aktivitas mengajar guru diperoleh dari perbandingan antara skor perolehan guru dan skor maksimum dikalikan seratus persen, maka persentase keberhasilan aktivitas mengajar guru pertemuan pertama adalah $83 \%$. Pada pertemuan kedua siklus II menunjukkan bahwa skor perolehan guru adalah 12 sedangkan skor maksimum 12. Maka persentase keberhasilan aktivitas mengajar guru pertemuan kedua adalah $100 \%$.

Hasil observasi aktivitas belajar siswa pada siklus II pertemuan pertama menunjukkan bahwa skor yang diperoleh adalah 9 sedangkan skor maksimum adalah 12. Persentase keberhasilan aktivitas belajar siswa diperoleh dari perbandingan antara skor perolehan dari aktivitas belajar siswa dan skor maksimum dikalikan seratus persen, maka persentase keberhasilan aktivitas belajar siswa pertemuan pertama adalah $75 \%$. Pada pertemuan kedua siklus II menunjukkan skor yang diperoleh dari aktivitas belajar siswa adalah 11 sedangkan skor maksimum 12. Maka persentase keberhasilan aktivitas belajar siswa pada pertemuan kedua adalah $91 \%$.

Berdasarkan hasil tes yang pada pelaksanaan pembelajaran yang dilakukan oleh guru sudah mencapai indikator dalam penelitian yaitu $80 \%$. Hasil belajar PKn secara klasikal yang memperoleh nilai $\geq 70$ sebanyak 10 siswa atau dengan persentase 90,90\% siswa mencapai KKM, sedangkan yang memperoleh nilai $<70$ sebanyak 1 siswa atau dengan persentase $9,1 \%$, dengan rata-rata 75,45 .

Hasil analisis ketuntasan belajar siswa pada penelitian hasil belajar secara klasikal dapat dilihat pada tabel berikut ini:

\section{Tabel 2. Analisis Ketuntasan Hasil Belajar Siswa Pada Siklus II}

\begin{tabular}{|c|c|c|c|c|}
\hline No & $\begin{array}{c}\text { Ketunta } \\
\text { san }\end{array}$ & Skor & $\begin{array}{c}\text { Jumlah } \\
\text { siswa }\end{array}$ & $\begin{array}{c}\text { Persentase } \\
(\%)\end{array}$ \\
\hline 1 & Tuntas & $70-100$ & 10 & $90,90 \%$ \\
\hline 2 & $\begin{array}{c}\text { Belum } \\
\text { Tuntas }\end{array}$ & $0-69$ & 1 & $9,1 \%$ \\
\hline \multicolumn{2}{|l|}{ Total } & 11 & $100 \%$ \\
\hline
\end{tabular}

Ketercapaian aktivitas guru dan siswa dalam proses pembelajaran pada siklus II yaitu pertemuan pertama aktivitas guru sebesar $85 \%$ dan pertemuan kedua meningkat menjadi $100 \%$. Sedangkan aktivitas belajar siswa siklus II yaitu pertemuan pertama sebesar $75 \%$ dan pertemuan kedua meningkat menjadi $91 \%$.

Berdasarkan hasil tes belajar siswa pada siklus II, siswa yang memperoleh nilai $\geq 70$ sebanyak 10 orang siswa atau sebesar $90,90 \%$ dengan nilai rata-rata 75,45 . Secara klasikal mencapai persentase ketuntasan yaitu $90,90 \%$ telah mencapai target yaitu $80 \%$. Ini pula mengalami peningkatan sebesar $27,27 \%$ dari hasil tes yang diperoleh pada siklus I.

Dari hasil tes belajar siswa yang diperoleh pada siklus II, dapat dikatakan bahwa penerapan model pembelajaran kooperatif tipe TPS memberikan dampak yang positif terhadap hasil 
belajar siswa. Hal ini sejalan dengan pendapatyang menyatakan bahwa model pembelajaran kooperatif adalah rangkaian kegiatan belajar yang dilakukan oleh siswa dalam kelompokkelompok tertentu untuk mencapai tujuan pembelajaran yang telah dirumuskan (Mohamad Syarif Sumantri, 2015, p.49).

Indikator keberhasilan dalam penelitian ini telah tercapai, dalam hal ini minimal $80 \%$ siswa telah mencapai nilai $\geq 70$, maka penelitian ini dihentikan sampai pada siklus II. Ini berarti bahwa, hipotesis tindakan telah terjawab yaitu dengan melalui penerapan model pembelajaran kooperatif tipe TPS hasil belajar PKn siswa pada materi pokok kebebasan berorganisai kelas SDN3 Toronipa dapat ditingkatkan.

\section{Simpulan}

Berdasarkan hasil penelitian dan pembahasan pada setiap siklus dari penelitian ini, maka dapat disimpulkan bahwa penerapan model pembelajaran kooperatif tipe TPS dapat meningkatkan hasil belajar siswa pada materi pokok kebebasan berorganisasi di kelas V SDN 3 Toronipa. Peningkatan terlihat dari hasil tes belajar siswa, ketuntasan klasikal siswa pada siklus I mencapai $63,63 \%$ dengan nilai rata-rata 67,72 sedangkan pada siklus II ketuntasan klasikal siswa meningkat menjadi $90,90 \%$ dengan nilai rata-rata 75,45.

\section{DAFTAR PUSTAKA}

Agung, Iskandar. 2012. Menghasilkan Guru Kompeten \& Profesional. Jakarta: Bee Media Indonesia.

Iru, La dan La Ode Safiun Arihi. 2012. Analisis Penerapan Pendekatan, Metode, Strategi, dan Modelmodel Pembelajaran. Kendari: Multi Presindo.
Kurniasih, I. dan Berlin S. 2014. Teknik dan Cara Mudah Membuat Penelitian Tindakan Kelas untuk Pengembangan Profesi Guru. Jakarta: Kata Pena.

Nursayang. 2012. Penerapan Model Pembelajaran Kooperatif Tipe Think Pair Share Untuk meningkatkan Hasil Belajar PKn Siswa Pada Materi Sistem Pemerintahan Desa Di Kelas IV SD Negeri 14 Mandonga Kota Kendari. Kendari: FKIP UHO.

Susanto, Ahmad. 2012. Teori Belajar dan Pembelajaran di Sekolah Dasar. Jakarta: Prenadamedia Group.

Thobroni, M. 2015. Belajar \& Pembelajaran Teori dan Praktik. Yogyakarta: Ar-Ruzz Media. 